部門主要任䅂的完成，即盡量地進一步提高所有 作物的產量，進一步增加公共牲畜的總數，同 時影著地提高音库品產量。

土㙲微生物祭家應該創造性地發展杜庫柴也 夫一一柯斯狄切夫一一威㡺士等科學的土埪學創 始人的學說，亚担負起任䅂，來理解士壤中保登 土壤肥力逐步提高的微生物學過程。

特别注意有關掌㩧草理輪作制及提高草田輪 作制效力的微生物學研究，间明樶正確的土壤耕 作方法, 研究更有效地施用略物質肥料和有機質 盵料的方法，以及研究細菌肥料的製備、储藏和 應用。

蘇聯微生物學家應該畫量將自己的研究協助 建造農田防護林帶的工作提高效力，並帮助防護 林截植用的樹木和灌木品種獲得高度存活率和馿 化。

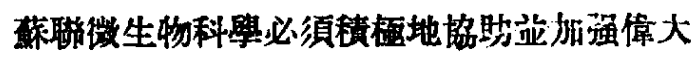
的斯大林共產主義建設的實現——伏爾加河、頓 河、德伯河和阿姆河的强大水力㡎電站、運河 和灌溉系統，逪些建設能於短期內在荒無人烟和 牛乾旱區域的開閐土地上以灌激和給水系統改造 大自然。

研究更有效的方法防治農作物由植物病原微 生物和病毒引起的病害, 避免其損失; 以及預防 费虐品储藏和加工㭙由微生物引起的損失。道 些問題對我們塥會主義農紧也有问樣重要意義 的。

在第十儿次黨代表大會上的馬林科夫闰志所 作的中央委員會報告中，我國莀業科學得到了正 確的郡價。馬林科夫說: “我們的農業科學對费

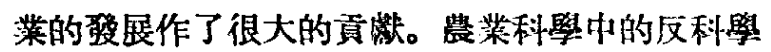
的、反動的思想已經被揭战和打倒了, 這門科學 現在是在唯一正確的基磼上一一在唯物主義的米 丘林學說的基礎上一一設展着, 並在發展農業的

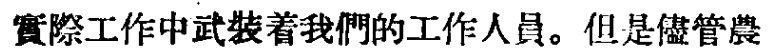

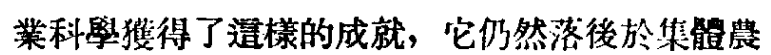
莊和國營農場生产的需要。龍會主義的農業制度 給科學開開了一佟貿阔的道路, 使我們能迅速推 夙科學成就和先進經驗, 使所有的集體農莊、農

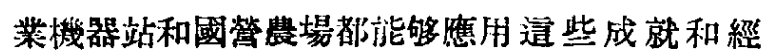
臨。”(馬林科夫，在第十儿次黨代表大會上關於 聯热（布）中央工作的總結報告。）

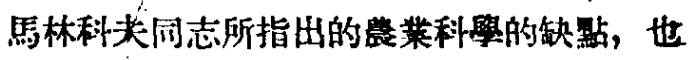

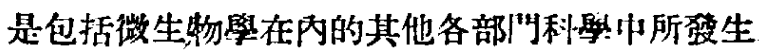
的集點。

注意迅速消滅䭴林科夫同志報告所指出的工 作中缺點，是在脤業微生物學領域中工作的微生 物學家的最重要任務，也是其他微生物典領域中 工作的微生物學家的最重要任䅂。

第年次五年計劃預見到輕工莱和食品工業的 淮一步頑著發展。

黨對食品工業的工作者不僅要求大大塒加彆 出的食品的數量, 而且還要求大大改進這些食品 的質量，首先是提高它們的營養價做。

款聯微生物學家必須在他們的研究工作中預 見玨造些要求亚且竭力使其資現。

我们的微生物科學應融皘梗地案與解决黨給 保健事業所提出的許多重要任務，而首先就是傳 染性病害預防的問題。

十儿次黨代表大會的指示要求特别注意最新

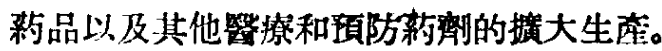

薣聯微生物學家會和竍多其他專業的科學工。

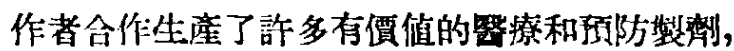
應垓加强力量在保健事業的賽践中尋梡研究新的 更加有效的抗生素製劑，並更迅速地倠用它們。

在蘇聯微生物學家面前的最重要任務中，應 該特别强調的，必須無情地揭露外國的反動學者

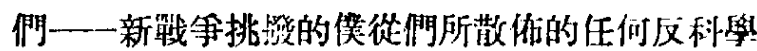
的仇親人類的觀忿。

必須無情地推露他們公開地或隐蔽地利用科

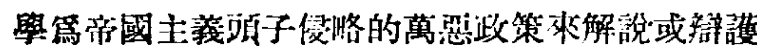
的任何企圖，無情地揭簬他們的反動的、沙文主 義的、仇視人類的思想。

篇着順利地望現十儿次灙代表大會對我國科 學提出的任務，所有决等性條件中们主装地位 的, 是對科學研究工作中的缺點大規榄地屡開批 部和自我批䛨。

斯大林闰志指示: “……如果汥有不间意思的

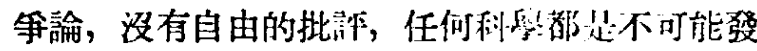
展, 不可能進步的。”這對蘇聯科學所有各部”的 發展起了很大的主好影齄。

批部和自我批詐隹該成篇我們日常工作中的 主要的經常起作用的工具，應該特别注意有系統 地舉行現代微生物學中的所有現䨘問題的刢选性 
的擢諭和廣䶸的邻諭。

在科學工作中的批評，首先隹㽬用來反對形 形色色的資湰階級思想的出現，反對任何唯心論 的臸曲。

“要始終一责地”實行批評和自我批評的口躆，

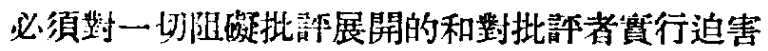
與報復的人進行堅决的挒拿。”（馬林利夫，在第 十儿次黨代表大會上關於聯共 (布) 中央工作的 總結報告）這是我們在資際工作中應該途循的信 佟。

蔡聯學者第着有力地促進攏在整㑬國家面前 的偉大的新五作計劃任務順利䒈現, 必須盡力加 强科學和筫践的創造性合作, 經常地給生産上的 革新者、新的先進工作者以多方面的聲助與支援。

我們的列密格勒的科學家們，在我國首創了 科學工作者和生产工作者的刢造性合作的受國主 義運動, 並已獾得詐多有價值的成果。利學研究 機關中工作者的最重要任䅂，是畵力像助這種就 會主義方式的科學和貨踐相不聯系的工作進一步 發展。(編者按：人包日報1902年12月16日和23日 的“蘇聯報刊論文摘要” 以及科學通報 1953 年 2

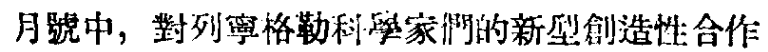
有簡單介紹。）

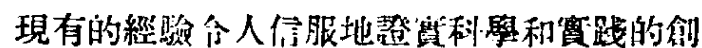
造性合作，不僅㑛國是經湾的重要阔題能得到成

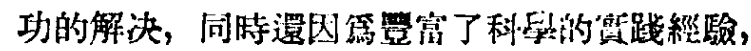
對科學本身的翟展也有極展好的影綮。

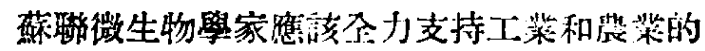

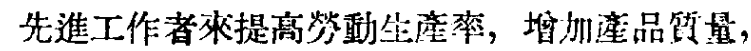
減低成本; 亚涊篇這些是他們最重要任移之一。 必須有系統地全面研究並總結生笙革 新 者的 經

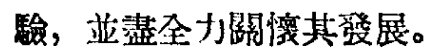

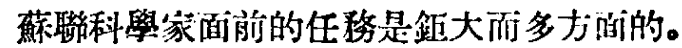

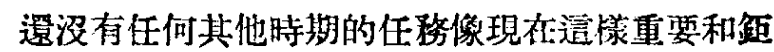

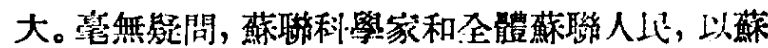
聯共産黨十九次代表大會的歷史性决定和斯大林

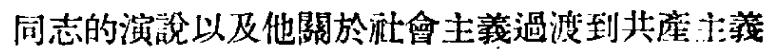
的道路的學䯪武裝了自己，用新的發現和發明充 赛我們的科學，盡力取得新的卓避成就来祦助促 進蘇聯發展第五次五年計劃的完成及超额完成, 並且促成我們偉大的领袖、明友和警師，的瑟夫 維茂里昂諾維奇・斯大林的訫劃具體惯現。

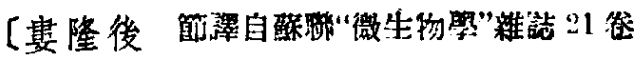
第 6 期, 1952 年 11-12月]

\section{〔上接 66 頁〕}

作。從出席代表來看, 事先廣泛徽求會員意 見不够, 有少數代表起而沒有做這樣的工作, 這 也是㤫當克服的缺點。

地理學會代表大會的經駋證明:（一)運用學 會代表大會的形式, 充分發拐民主, 以自由研究

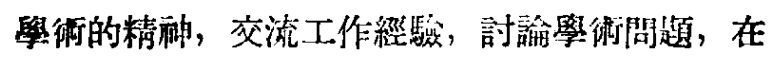
国結組織科學家，更好的服预於國家建設上，是 能起很大作用的。通過這一次代表人會, 不但地 理學家認清了租國經沾文化各方酤建設對於地理 學的殷切需要，因而管强了地理學者的重大資任 感與工作管心，同時也協助敎育部、科學院等领導 機關全面地了解了地理學界的翼際情况與存在的 閭題。（二)留議內容應該集中，才j針必須明確， 不能包羅太多, 企圖一次曾議解决訫多阔題, 會 前潐嘟必須无分。(三)學會召開前, 先與有關業 務部門多方聯系, 以便使學術工作能这好地筬國 家建設服咯, 並適賞地總結過去工作, 以便提出 進一步開屡工作的方針。

這次代表大會還只是全國地理工作者婟結合 作的開端, 今後應加强學會工作的計劃性, 在總 會理事會領導之下, 加强與各地分會的聯系, 有 步驟有重點地開展工作，以促進地理 科學的破 展。 